\title{
First report of Pythium coloratum causing root rot on hydroponically grown lettuce (Lactuca sativa L.) in Malaysia
}

\author{
Siti Izera Ismail ${ }^{1,2}$ (D) Shahara Ayub ${ }^{1}$ \\ Received: 24 June 2020 / Accepted: 26 February 2021 / Published online: 3 March 2021 \\ (c) Società Italiana di Patologia Vegetale (S.I.Pa.V.) 2021
}

Keywords Pythium coloratum $\cdot$ Root rot $\cdot$ Lettuce

In April 2019, green coral lettuce (Lactuca sativa L.) showing root rot symptoms (approximately $20 \%$ disease incidence) were observed in a hydroponic commercial greenhouse located at Genting Highland, Pahang, Malaysia. Symptoms appeared as necrotic lesions on the tap and lateral roots, and affected lettuce appeared stunted and wilted. Symptomatic roots were surface-sterilized by $70 \%$ ethanol, rinsed with sterile distilled water, cut into $0.5 \mathrm{~cm}$ pieces, and plated on PARP-V8 selective medium (Moorman et al. 2002). The colonies produced filamentous sporangia, $20 \mu \mathrm{m}$ yellowish and subglobose oogonia, and antheridia developed on branched stalks. Six isolates with similar morphological characteristics to Pythium coloratum (Van der Plaats-Niterink 1981) were obtained from tissue samples. The primer pair OomCoxI-Levup/OomCoxI-Levlo for cytochrome oxidase subunit 1 (COI) (Robideau et al. 2011) and ITS5/ITS4 for rDNA (White et al. 1990) were used for sequencing three representative isolates (PA, PB, and PC). The resulting sequences were deposited in the GenBank (COI Accession No. MW316679, MT996498, MW316680; ITS Accession No. MT659403, MT659403, MW316680). BLAST analysis of COI and ITS sequences showed 100\% identity to P. coloratum strain BR621 (HQ708550 and HQ643504, respectively), and $P$. coloratum voucher BR621 (HQ708550.1 and HQ643504.1, respectively). Isolates PA, PB and PC grouped in a strongly supported clade (100\%

Siti Izera Ismail

izera@upm.edu.my

1 Department of Plant Protection, Faculty of Agriculture, Universiti Putra Malaysia, Serdang, Selangor 43400, Malaysia

2 Laboratory of Climate-Smart Food Crop Production, Institute of Tropical Agriculture and Food Security (ITAFoS), Universiti Putra Malaysia, Serdang, Selangor 43400, Malaysia bootstrap) with reference strains of $P$. coloratum. Pathogenicity test were conducted on ten 4-week-old green coral lettuce seedlings grown hydroponically at $23{ }^{\circ} \mathrm{C}, 95 \%$ relative humidity with a photoperiod of 12 -h. The roots were inoculated by a suspension $\left(10^{6}\right.$ zoospores $\left./ \mathrm{ml}\right)$ of the PB strain. Control roots were placed in sterile deionised water. After 14 days, similar symptoms to those observed in the greenhouse appeared on inoculated roots, while control plants were asymptomatic. The pathogen was reisolated from symptomatic roots and morphologically and molecularly identified as P. coloratum. The reference isolate PB was deposited in the Microbial Collection Unit, Institute of Biosciences, University Putra Malaysia, with accession number UPMC 1451. To our knowledge, this is the first report of $P$. coloratum causing root rot of lettuce in Malaysia.

Supplementary Information The online version contains supplementary material available at https://doi.org/10.1007/s42161-021-00804-6.

\section{References}

Moorman GW, Kang S, Geiser DM, Kim SH (2002) Identification and characterization of Pythium species associated with greenhouse floral crops in Pennsylvania. Plant Dis 86(11):1227-1231

Robideau GP, De Cock AW, Coffey MD, Voglmayr H, Brouwer H, Bala K, Chitty DW, Desaulniers N, Eggertson QA, Gachon CM, $\mathrm{Hu} \mathrm{CH}$, Kupper FC, Rintoul TL, Sarhan E, Verstappen EC, Zhang Y, Bonants PJ, Ristaino JB, Lévesque CA (2011) DNA barcoding of oomycetes with cytochrome $\mathrm{c}$ oxidase subunit I and internal transcribed spacer. Mol Ecol Resour 11(6):1002-1011

van der Plaats-Niterink AJ (1981) Monograph of the genus Pythium, vol 21. Centraalbureau voor Schimmelcultures, Baarn

White TJ et al. (1990) Page 315 in: PCR Protocols: a Guide to Methods and Applications. Academic Press, San Diego, CA

Publisher's Note Springer Nature remains neutral with regard to jurisdictional claims in published maps and institutional affiliations. 